\title{
Korelasi Tipe Kepemimpinan Kepala Sekolah dan Lingkungan Kerja terhadap Kinerja Guru
}

\author{
N. L. Nidia Kustinayanti ${ }^{1}$, I Komang Ngurah Wiyasa ${ }^{2}$ \\ 1,2 Prodi Pendidikan Guru Sekolah Dasar, FIP, Universitas Pendidikan Ganesha \\ Singaraja, Indonesia \\ *e-mail: nidiayantikus@gmail.com¹,ngrh.wiyasa@undiksha.ac.id²
}

\begin{abstract}
Abstrak
Menurunnya kinerja guru diakibatkan oleh kepemimpinan kepala sekolah dan lingkungan kerja yang belum maksimal. Penelitian ini bertujuan untuk mengetahui korelasi tipe kepemimpinan kepala sekolah dan lingkungan kerja terhadap kinerja guru. Penelitian ini merupakan penelitian ex post facto. Populasi dari penelitian ini adalah 35 guru PNS. Teknik dalam pengambilan sampel ini menggunakan sampling total yaitu jumlah populasi sama dengan jumlah anggota dari sampelnya. Metode pengumpulan data dalam penelitian ini menggunakan metode non tes. Data tipe kepemimpinan kepala sekolah dan lingkungan kerja diperoleh dengan penyebaran kuesioner dan data kinerja guru diperoleh melalui pencatatan dokumen. Uji hipotesis dilakukan dengan uji analisis korelasi product moment dan uji analisis korelasi ganda. Hasil penelitian menunjukkan bahwa terdapat korelasi yang signifikan tipe kepemimpinan kepala sekolah terhadap kinerja guru dengan nilai $0,842 \geq 0,334$, terdapat korelasi yang signifikan lingkungan kerja terhadap kinerja guru dengan nilai $0,842 \geq 0,334$, serta terdapat korelasi yang signifikan antara tipe kepemimpinan kepala sekolah dan lingkungan kerja terhadap kinerja guru dengan nilai $0,862 \geq 0,334$. Sehingga dapat disimpulkan bahwa terdapat korelasi yang signifikan antara tipe kepemimpinan kepala sekolah dan lingkungan kerja terhadap kinerja guru.
\end{abstract}

Kata kunci: Tipe Kepemimpinan, Lingkungan, Kinerja Guru

\begin{abstract}
The decline in teacher performance is due to the principal's leadership and the work environment that is not optimal. This study was aimed at determining the correlation between the type of principal leadership and work environment on teachers' performance. The study was an ex-post facto research. The population of this study were 35 civil servant teachers. The sampling technique used was the total sampling technique, which means the number of populations equals the number of samples. The data collection method was the non-test method. The data for the type of principal leadership and work environment were obtained by distributing questionnaires and the data for teachers' performance were obtained by doing the document recording method. Hypothesis testing was carried out by using the product moment correlation analysis test and multiple correlation analysis. The results showed that there is a significant correlation between the type of principal leadership and performance of the teacher $0.842 \geq 0.334$, there is a significant correlation of work environment on teachers' performance $0.842 \geq 0.334$, and there is a significant correlation between the type of principal leadership and the work environment on teachers' performance 0,862 $\geq 0,334$. So it can be concluded that there is a significant correlation between the type of principal leadership and the work environment on teacher performance.
\end{abstract}

Keywords: Leadership Type, Environment, Teachers' Performance

\section{Pendahuluan}

Guru merupakan salah satu sumber daya manusia yang berada di sekolah. Guru yang profesional akan mempertaruhkan profesi pada kualitas kerjanya. Guru yang berkualitas pasti bisa meningkatkan kinerjanya agar dapat mencapai hasil kerja yang diinginkan serta mewujudkan tujuan yang telah ditetapkan (Mbuik, 2019). Berbagai usaha dilakukan untuk mencapai kinerja yang baik. 
Kinerja guru dapat dilihat dari proses dalam melaksanakan tugas dan tanggung jawabnya sebagai guru seperti perencanaan pelaksanaan kegiatan pembelajaran, pelaksanaan kegiatan, dan evaluasi atau penilaian (Harefa, 2019). Kinerja bisa diukur jika seorang tersebut sudah mempunyai standar keberhasilan yang dapat dijadikan sebagai acuan organisasi dalam mencapai suatu tujuan yang telah ditentukan (Priyono et al., 2018). Kinerja guru merupakan sebuah hasil kerja yang dimiliki seorang guru yang keahliannya lebih bisa ditingkatkan lagi dalam dunia pendidikan untuk dapat meningkatkan mutu pendidikan di sekolah sekaligus memajukan anak bangsa (Nainggolan et al., 2018; Rosaliawati et al., 2020). Kinerja dari seorang guru ditentukan dari keberhasilan guru dalam menjalankan tugas dan tanggung jawab dalam proses pembelajaran sesuai dengan standar kinerja yang telah ditetapkan untuk mencapai tujuan sekolah (Fredianto, 2016). Jadi dapat disimpulkan bahwa kinerja guru merupakan hal yang sangat penting dalam pencapaian hasil kerja yang dilakukan selama bekerja. Akan tetapi ada saja guru yang kinerjanya rendah dan tidak memiliki rasa semangat untuk bekerja. Hal tersebut yang pastinya akan menghambat semua pekerjaan sehingga apa yang diharapkan dari seorang guru tidak tercapai termasuk sulit tercapainya tujuan sekolah (Siagian, 2018; Suryani et al., 2017). Mengingat pentingnya kinerja guru dalam pendidikan, maka diperlukan upaya untuk meningkatkan kinerja dari seorang guru. Berdasarkan hal tersebut banyak faktor yang dapat mempengaruhi kinerja guru.

Ada dua faktor yang mempengaruhi kinerja guru yaitu faktor internal dan faktor eksternal (Fauzyah, 2020). Faktor internal kinerja guru adalah faktor yang terdapat dari kemampuan atau potensi yang dimiliki seseorang yang terdapat dalam dirinya serta keterampilan yang dimiliki oleh seorang guru itu sendiri, yaitu terkait pengetahuan dan keterampilan dalam mengajarnya. Sedangkan faktor eksternal kinerja guru yaitu faktor yang datang dari luar guru yang dapat memengaruhi kinerjanya seperti kepemimpinan kepala sekolah dan lingkungan kerja (Putri, 2017). Kepemimpinan yang diperankan oleh kepala sekolah memiliki pengaruh terhadap kinerja guru (Azis \& Suwatno, 2019; Sumarni et al., 2017). Kepala sekolah mempunyai peran yang sangat penting dalam mempengaruhi, membimbing, mengkoordinir dan menggerakkan orang-orang termasuk guru maupun siswa (Astuti, 2018; Isnaini, 2019). Kepemimpinan kepala sekolah merupakan cara pemimpin dalam mewujudkan visi, misi, tujuan dan sasaran sekolah melalui program program yang dilaksanakan secara terencana dan bertahap (Muslimin, 2019). Dengan begitu untuk menunjang kinerja guru dalam proses pembelajaran di sekolah perlu adanya keberadaan dari kepala sekolah untuk dapat memimpin sekolah dan memberikan arahan yang baik kepada bawahan. Perilaku kepala sekolah yang positif dapat mengarah dan memotivasi individu guru, karena apapun yang dikerjakan oleh guru pasti meminta pertimbangan dari kepala sekolah sehingga tujuan pendidikan di sekolah tersebut dapat tercapai (Anwar, 2019; Candra \& Sakban, 2016).

Selain dari kepemimpinan kepala sekolah, lingkungan kerja merupakan faktor penting yang dapat mempengaruhi kinerja guru (Eliyanto, 2018; Elly \& Soraya, 2020). Lingkungan kerja merupakan segala hal yang terjadi dalam melakukan kegiatan disekitar tempat bekerja yang dapat mempengaruhi pekerjanya dalam menjalankan tugas-tugas yang dibebankan baik secara fisik maupun non fisik (Nefrida, 2016). Manusia mampu melaksanakan kegiatannya dengan baik dan optimal apabila diantaranya ditunjang oleh suatu kondisi lingkungan yang sesuai (Ferawati, 2017). Lingkungan kerja yang kondusif tentunya dapat memberikan rasa yang aman untuk bekerja dan juga mereka bisa betah untuk bekerja (Anam, 2018; Fachreza et al., 2018). Seorang guru tentu saja mengharapkan lingkungan tempat mereka bekerja menjadi lingkungan yang aman, nyaman dan tentram (Siagian, 2018). Sehingga dengan adanya lingkungan kerja yang aman, nyaman dan tentram dapat meningkatkan pencapaian kinerja guru secara maksimal dan baik.

Berdasarkan hasil pengamatan dan observasi yang telah saya lakukan di SD Gugus Srikandi terdapat beberapa permasalahan yang menyebabkan menurunnya kinerja guru yaitu kurang adanya pengalaman dan pemahaman guru akan metode dan strategi yang digunakan dalam pelaksanaan pembelajaran daring, dimana pada masa 
pandemic Covid-19 ini guru harus paham dengan penggunaan teknologi dan juga melakukan perubahan pola mengajar yang sebelumnya tatap muka menjadi pembelajaran berbasis daring yang membatasi guru untuk mengamati, mengajar, mendidik dan memberikan penilaian secara nyata kepada siswa sehingga hal tersebut yang membuat guru-guru kurang bersemangat dalam menjalankan tugas dan kewajiban yang diberikan. Maka hal inilah yang berdampak kepada pada rendahnya hasil kinerja guru di sekolah tersebut. Hasil pengamatan tersebut sesuai dengan penelitian yang dilakukan oleh (Ansori, 2019) yang mengatakan bahwa masalah kinerja selalu mendapat perhatian dalam manajemen karena sangat berkaitan erat dengan produktivitas lembaga atau organisasi karena hal utama yang mempengaruhi kinerja adalah kemampuan dan kemauan. Jika seorang tersebut mau tetapi tidak mampu dan sebaliknya orang tersebut mampu tetapi tidak mau maka sudah pasti kinerjanya tidak dapat dihasilkan dengan baik karena tidak adanya keseimbangan antara kemampuan dan kemauan dan jika seorang tersebut seimbang antara kemampuan dan kemauannya sudah pasti kinerja yang dihasilkan sangat baik. Maka dari itu sangatlah penting untuk dapat meningkatkan kinerja guru sebagai salah satu upaya meningkatkan kualitas pendidikan di sekolah tersebut, karena kinerja guru yang tinggi merupakan perwujudan kualitas guru (Candra \& Sakban, 2016; Ideswal, 2019).

Berdasarkan dari pemaparan tersebut, tujuan dari penelitian ini adalah untuk mengetahui korelasi tipe kepemimpinan kepala sekolah dan lingkungan kerja terhadap kinerja guru di SD Gugus Srikandi. Hal ini didukung oleh penelitian relevan yang dilakukan oleh (Anam, 2018; Astuti, 2018; Hardono, 2017) dalam penelitiannya menunjukkan bahwa terdapat pengaruh yang positif dan signifikan kepemimpinan kepala sekolah, supervisi akademik, lingkungan kerja, dan motivasi kerja terhadap kinerja guru. Kepemimpinan kepala sekolah, supervisi akademik, lingkungan kerja dan motivasi kerja yang baik akan meningkatkan kinerja guru. Kemudian penelitian yang dilakukan oleh (Sampurno, 2015) menyatakan bahwa kepemimpinan kepala sekolah dan lingkungan kerja berpengaruh secara parsial terhadap motivasi kerja guru, hal itu berarti bahwa kepemimpinan kepala sekolah dan lingkungan kerja memiliki pengaruh langsung terhadap motivasi kerja guru. Karena kepeminpinan kepala sekolah berpengaruh parsial terhadap kinerja guru, maka bisa dinyatakan bahwa kepemimpinan kepala sekolah berpengaruh langsung terhadap kinerja guru. Selanjutnya, karena motivasi kerja tidak berpengaruh terhadap kinerja guru, maka kepemimpinan kepala sekolah dan lingkungan kerja tidak memiliki pengaruh tidak langsung terhadap kinerja guru. Penelitian yang dilakukan memiliki perbedaan dari penelitian lainnya dimana masa pandemic covid ini sangat sulit turun langsung untuk melaksanakan penelitian sehingga observasi dilakukan secara daring kepada sekolah yang dituju dengan memberikan kuesioner secara daring kepada guru-guru PNS untuk melihat bagaimana kinerja dari seorang guru selama masa pandemic karena salah satu aspek yang menarik untuk dikaji dari sosok seorang guru adalah aspek kinerjanya.

\section{Metode}

Penelitian ini dilakukan pada guru PNS di SD Gugus Srikandi yang terdiri dari 6 sekolah. Keenam sekolah tersebut adalah SD Negeri 1 Sumerta, SD Negeri 2 Sumerta, SD Negeri 5 Sumerta, SD Negeri 8 Sumerta, SD Negeri 10 Sumerta, SD Negeri 13 Kesiman. Pemilihan SD Gugus Srikandi sebagai tempat penelitian karena keterjangkauan tempat penelitian ini mudah dijangkau oleh peneliti serta kelayakannya di SD Gugus Srikandi ini belum pernah dilakukan penelitian yang sama dengan penelitian ini. Penelitian ini menggunakan rancangan penelitian ex post facto dengan jenis penelitian korelasional. Adapun variabel dalam penelitian ini terdiri dari tipe kepemimpinan kepala sekolah dan lingkungan kerja sebagai variabel bebas (X) serta kinerja guru sebagai variabel terikat $(\mathrm{Y})$.

Populasi dalam penelitian ini adalah seluruh guru PNS yang ada di SD Gugus Srikandi yang berjumlah 35 Guru. Teknik pengambilan sampel dalam penelitian ini 
adalah sampling total sehingga sampel penelitian adalah guru-guru di SD Gugus Srikandi yang berkualifikasi PNS dengan jumlah 35 orang. Instrumen yang digunakan dalam pengambilan data adalah non-tes berupa angket dan pencatatan dokumen. Angket digunakan untuk mengetahui data tipe kepemimpinan sekolah dan lingkungan kerja menggunakan skala likert dengan jumlah pernyataan masing-masing 32 butir, serta pencatatan dokumen untuk mengetahui data kinerja guru menggunakan hasil penilaian kinerja guru yang sebelumnya dinilai oleh kepala sekolah. Adapun kisi-kisi dan indikator dari instrument penelitian untuk memperoleh data variabel tipe kepemimpinan kepala sekolah, pada Tabel 1.

Tabel 1. Kisi-Kisi dan Indikator Instrumen Penelitian Tipe Kepemimpinan Kepala Sekolah $\left(\mathrm{X}_{1}\right)$

\begin{tabular}{|c|c|c|c|c|c|}
\hline \multirow[b]{2}{*}{ Dimensi } & \multirow[b]{2}{*}{ Indikator } & \multirow{2}{*}{$\begin{array}{l}\text { Jml } \\
\text { Butir } \\
\text { Soal }\end{array}$} & \multirow{2}{*}{$\begin{array}{l}\text { No. } \\
\text { Butir } \\
\text { Soal }\end{array}$} & \multicolumn{2}{|c|}{ Butir } \\
\hline & & & & $(+)$ & $(-)$ \\
\hline \multirow{8}{*}{$\begin{array}{l}\text { 1. Tipe } \\
\text { Kepemimpin } \\
\text { an Otokratis }\end{array}$} & $\begin{array}{l}\text { 1. Pemimpin } \\
\text { wewenang penuh terhadap } \\
\text { kebijakan dan penetapan } \\
\text { peraturan sekolah. }\end{array}$ & 3 & $\begin{array}{c}2 \\
14 \\
34\end{array}$ & $\begin{array}{c}1,4,3 \\
4\end{array}$ & 2 \\
\hline & $\begin{array}{l}\text { 2. Teknik dan langkah-langkah } \\
\text { aktivitas ditentukan oleh } \\
\text { pemimpin sehingga membatasi } \\
\text { kreativitas guru. }\end{array}$ & 3 & $\begin{array}{c}1 \\
13 \\
35\end{array}$ & 1 & $\begin{array}{c}13,3 \\
5\end{array}$ \\
\hline & $\begin{array}{l}\text { 3. Pemimpin biasanya mendikte } \\
\text { tugas pekerjaan khusus dan } \\
\text { teman sekerja setiap guru. }\end{array}$ & 3 & $\begin{array}{c}4 \\
16 \\
32\end{array}$ & 4 & $\begin{array}{l}16 \\
32\end{array}$ \\
\hline & $\begin{array}{l}\text { 4. Pemimpin cenderung bersikap } \\
\text { pribadi atau tidak mau } \\
\text { menerima kritikan dari guru. }\end{array}$ & 3 & $\begin{array}{l}3 \\
15 \\
33\end{array}$ & 15 & 3,33 \\
\hline & $\begin{array}{l}\text { 5. Pemimpin memberikan } \\
\text { kebebasan penuh dalam } \\
\text { mengambil keputusan baik } \\
\text { secara kelompok atau individual } \\
\text { dengan minimum partisipasi } \\
\text { pemimpin bahkan terkesan acuh } \\
\text { tak acuh. }\end{array}$ & 3 & $\begin{array}{c}6 \\
18 \\
30\end{array}$ & 18 & 6,30 \\
\hline & $\begin{array}{l}\text { 1. Pemimpin memberikan } \\
\text { kebebasan mutlak kepada guru } \\
\text { dalam menentukan segala } \\
\text { sesuatu yang berguna bagi } \\
\text { kemajuan organisasinya tanpa } \\
\text { bimbingan darinya. }\end{array}$ & 3 & $\begin{array}{l}5 \\
17 \\
31\end{array}$ & 5 & $\begin{array}{l}17 \\
31\end{array}$ \\
\hline & $\begin{array}{l}\text { 2. Pemimpin tidak berpartisipasi } \\
\text { sama sekali dalam organisasi } \\
\text { yang dipimpinnya. }\end{array}$ & 3 & $\begin{array}{c}7 \\
19 \\
29\end{array}$ & 29 & 7,19 \\
\hline & $\begin{array}{l}\text { 3. Pemimpin memberikan } \\
\text { komentar spontan atas } \\
\text { aktivitas-aktivitas anggota dan } \\
\text { ia tidak menilai atau tidak } \\
\text { melakukan evaluasi terhadap } \\
\text { kinerja guru. }\end{array}$ & 3 & $\begin{array}{l}9 \\
21 \\
27\end{array}$ & 9,21 & 27 \\
\hline
\end{tabular}




\begin{tabular}{|c|c|c|c|c|c|}
\hline \multirow[b]{2}{*}{ Dimensi } & \multirow[b]{2}{*}{ Indikator } & \multirow{2}{*}{$\begin{array}{c}\text { Jml } \\
\text { Butir } \\
\text { Soal }\end{array}$} & \multirow{2}{*}{$\begin{array}{l}\text { No. } \\
\text { Butir } \\
\text { Soal }\end{array}$} & \multicolumn{2}{|c|}{ Butir } \\
\hline & & & & $(+)$ & $(-)$ \\
\hline \multirow{5}{*}{$\begin{array}{l}\text { 3. Tipe } \\
\text { Kepemimpi } \\
\text { nan } \\
\text { Demokratis }\end{array}$} & $\begin{array}{l}\text { 1. Pemimpin bersama-sama guru } \\
\text { berperan aktif dalam perumusan } \\
\text { dan penetapan peraturan } \\
\text { secara umum dan keputusan- } \\
\text { keputusan penting dalam } \\
\text { sekolah. }\end{array}$ & 3 & $\begin{array}{c}8 \\
20 \\
28\end{array}$ & 20,28 & 8 \\
\hline & $\begin{array}{l}\text { 2. Pemimpin selalu berupaya } \\
\text { menghargai potensi setiap } \\
\text { individu. }\end{array}$ & 3 & $\begin{array}{l}11, \\
23, \\
25\end{array}$ & 11,23 & 25 \\
\hline & $\begin{array}{l}\text { 3. Para anggota bebas untuk } \\
\text { bekerja dengan siapa yang } \\
\text { mereka kehendaki tanpa } \\
\text { membatasi kreativitas yang } \\
\text { dilakukan oleh bawahannya }\end{array}$ & 3 & $\begin{array}{l}10 \\
22, \\
26\end{array}$ & 22,26 & 10 \\
\hline & $\begin{array}{l}\text { 4. Pemimpin bersifat obyektif } \\
\text { dalam pujian dan kritiknya }\end{array}$ & 2 & $\begin{array}{l}12 \\
24\end{array}$ & 12 & 24 \\
\hline & Jumlah & & 35 & & \\
\hline
\end{tabular}

Tabel 2. Kisi-kisi dan Indikator Instrumen Penelitian Lingkungan Kerja $\left(\mathrm{X}_{2}\right)$

\begin{tabular}{|c|c|c|c|c|c|}
\hline \multirow{2}{*}{ Dimensi } & \multirow{2}{*}{ Indikator } & \multirow{2}{*}{$\begin{array}{l}\text { Jml } \\
\text { Butir } \\
\text { Soal }\end{array}$} & \multirow{2}{*}{$\begin{array}{l}\text { No. } \\
\text { Butir } \\
\text { Soal }\end{array}$} & \multicolumn{2}{|c|}{ Butir } \\
\hline & & & & $(+)$ & $(-)$ \\
\hline \multirow{6}{*}{$\begin{array}{l}\text { 1. Lingkungan } \\
\text { Kerja Fisik }\end{array}$} & 2. Penerangan & 3 & $1,20,21$ & 1,21 & 20 \\
\hline & 3. Suhu Udara & 4 & $2,19,22,31$ & 2,22 & $\begin{array}{c}19,3 \\
1\end{array}$ \\
\hline & 4. Tata ruang & 3 & $3,18,23$ & 3,18 & 23 \\
\hline & 5. Keamanan & 3 & $4,17,24$ & 4,24 & 17 \\
\hline & 6. Kebersihan & 4 & $5,16,25,32$ & 5,25 & $\begin{array}{c}16,3 \\
2\end{array}$ \\
\hline & 7. Kebisingan & 3 & $6,15,26$ & 15 & 6,26 \\
\hline \multirow{4}{*}{$\begin{array}{l}\text { 2. Lingkungan } \\
\text { Kerja Non } \\
\text { Fisik }\end{array}$} & 1. Tanggung Jawab & 4 & $7,14,27,33$ & 7,27 & $\begin{array}{c}14,3 \\
3\end{array}$ \\
\hline & 2. Perhatian dan & 3 & $8,13,28$ & 8,28 & 13 \\
\hline & $\begin{array}{l}\text { 3. Hubungan antar } \\
\text { Sesama Guru }\end{array}$ & 4 & $9,12,29,34$ & 9,29 & $\begin{array}{c}12,3 \\
4\end{array}$ \\
\hline & $\begin{array}{l}\text { 4. Kelancaran } \\
\text { Komunikasi }\end{array}$ & 4 & $\begin{array}{c}10,11,30,3 \\
5\end{array}$ & $\begin{array}{c}10,3 \\
0\end{array}$ & $\begin{array}{c}11,3 \\
5\end{array}$ \\
\hline & Jumlah & & 35 & & \\
\hline
\end{tabular}

Untuk mendapatkan data yang baik perlu dilakukanya beberapa uji instrumen, uji yang digunakan dalam penelitian ini yaitu uji validitas konstruk berkaitan dengan validitas teoretik yang diuji oleh judges untuk mengetahui kelayakan instrument bedasarkan kesesuaian antara grand theory, kisi-kisi terhadap butir pernyataan. Serta uji validitas butir menggunakan rumus korelasi product moment dengan hasil diperoleh 32 pernyataan valid dari 35 butir instrumen tipe kepemimpinan kepala sekolah $\left(X_{1}\right)$ dan diperoleh 32 pernyataan valid dari 35 butir instrumen lingkungan kerja $\left(X_{2}\right)$. Dan uji reliabilitas menggunakan alpha cronbach diperoleh hasil reliabilitas tinggi pada kedua instrument penelitian. Setelah instrumen dinyatakan layak maka 
dilaksanakan pengumpulan data ke lapangan. Data yang telah diperoleh kemudian di analisa, dengan menggunakan analisis statistik deksriptif dan inferensial. Sebelum dianalisa lebih lanjut dilakukan uji asumsi klasik untuk mengetahui apakah data tersebut layak dianaliasis lebih lanjut menggunakan uji normalitas sebaran data, uji linieritas dan uji multikolinieritas. Apabila seluruh uji asumsi telah terpenuhi maka dilanjutkan analisa pengujian hipotesis menggunakan statistik parametrik product moment dan korelasi ganda.

\section{Hasil dan Pembahasan}

Berdasarkan data yang telah dikumpulkan dengan memberikan angket kepada guru PNS dan pencatatan dokumen. Adapun hasil pengujian statistika deskriptif untuk mendeskripsikan data agar mudah diamati, data yang telah diperoleh, disajikan menggunakan tabel sebagai berikut pada Tabel 3.

Tabel 3. Deskripsi data Tipe Kepemimpinan, Lingkungan Kerja dan Kinerja Guru

\begin{tabular}{lccc}
\hline \multirow{2}{*}{ Statistika } & \multicolumn{3}{c}{ Variabel } \\
\cline { 2 - 4 } & $\begin{array}{c}\text { Korelasi Tipe } \\
\text { Kepemimpinan } \\
\text { Kepala Sekolah }\end{array}$ & Lingkungan Kerja & Kinerja Guru \\
\hline Jumlah Sempel & 35 & 35 & 35 \\
Mean & 107,40 & 111,80 & 88,78 \\
Median & 108 & 116 & 89,29 \\
Modus & 98 & 100 & 85.71 \\
Skor Maksimum & 120 & 128 & 98,21 \\
Skor Minimum & 89 & 90 & 76,79 \\
Standar Deviasi & 9.28 & 11,74 & 5,40 \\
Varians & 86,19 & 137,75 & 29.18 \\
\hline
\end{tabular}

Bedasarkan Tabel 3, yang telah disajikan, data dianalisis menggunakan analisis deskriptif sehingga diperoleh skor maksimum, minimum, rata-rata, varians dan standar deviasi dari tipe kepemimpinan kepala sekolah, lingkungan kerja dan kinerja guru. Sebelum diuji secara lebih lanjut, data diuji kesyaratannya antara lain uji normalitas sebaran data, uji linieritas, dan uji multikoliniearitas. Uji prasyarat ini diteliti berbantuan IBM SPSS Statistic 22.0. Hasil uji prasyarat pertama yaitu uji normalitas, untuk mengetahui apakah data yang diteliti telah berdistribusi normal atau tidak dengan menggunakan rumus Kolmogorov Smirnov. Pengujian ini dilakukan dengan menggunakan taraf signifikan sebesar $0,05 \%$. Adapun hasil uji normalitas disajikan sebagai berikut.

Tabel 4. Hasil Uji Normalitas Residual X1, X2 dan Y

\begin{tabular}{lcc}
\hline \multicolumn{1}{c}{ Variabel } & Kolmogorov Smirnov & Keterangan \\
\hline Tipe Kepemimpinan Kepala Sekolah & 0,082 & Normal \\
Lingkungan Kerja & 0,071 & Normal \\
Tipe Kepemimpinan Kepala Sekolah dan & 0,0745 & Normal \\
Lingkungan Kerja terhadap Kinerja Guru & & \\
\hline
\end{tabular}

Berdasarkan tabel diatas diketahui bahwa nilai KS hitung untuk residual variabel tipe kepemimpinan kepala sekolah, lingkungan kerja dan gabungan dari kedua variable terhadap kinerja guru adalah sebesar $0.082,0.071$ dan 0.0745 atau memiliki nilai lebih kecil dari nilai $K S$ Tabel dengan $n=35$ dan alpha $=5 \%$ yaitu sebesar 0.23 , sehingga dapat disimpulkan bahwa data variabel tipe kepemimpinan kepala sekolah dan lingkungan kerja terhadap kinerja guru berdistribusi normal. Selanjutnya Hasil uji prasyarat kedua yaitu uji liniearitas bentuk hubungan antara variabel bebas dengan 
variabel terikat, dimana data diolah menggunakan IBM SPSS Statistic 22.0. Uji linieritas digunakan untuk mengetahui apakah terdapat hubungan yang linier antara variabel penelitian. Adapun hasil uji linieritas disajikan pada Tabel 5.

Tabel 5. Hasil Uji Liniearitas Tipe Kepemimpinan Kepala Sekolah terhadap Kinerja Guru

\begin{tabular}{|c|c|c|c|c|c|c|c|}
\hline & & & $\begin{array}{l}\text { Sum of } \\
\text { Squares }\end{array}$ & Df & $\begin{array}{l}\text { Mean } \\
\text { Square }\end{array}$ & $\mathbf{F}$ & Sig. \\
\hline Kinerja Guru * & & (Combined) & 839,591 & 21 & 39,981 & 3,409 & 0,013 \\
\hline Tipe & Between & Linearity & 703,552 & 1 & 703,552 & 59,989 & 0,000 \\
\hline $\begin{array}{l}\text { Kepemimpinan } \\
\text { Kepala Sekolah }\end{array}$ & Groups & $\begin{array}{l}\text { Deviation } \\
\text { from Linearity }\end{array}$ & 136,039 & 20 & 6,802 & 0,580 & 0,868 \\
\hline & hin Group & & 152,464 & 13 & 11,728 & & \\
\hline
\end{tabular}

Pada Tabel di atas terlihat bahwa nilai $F$ hitung pada uji keberartian (linearity) adalah 59,989 dan nilai $F$ hitung pada uji linearitas (Deviation from Linearity) adalah 0,580. Dengan kata lain maka dapat dinyatakan bahwa hubungan antara tipe kepemimpinan kepala sekolah terhadap kinerja guru bersifat linier. Hasil perhitungan pengujian linieritas hubungan antara variabel lingkungan kerja terhadap kinerja guru bisa dilihat pada Tabel 6.

Tabel 6. Hasil Uji Liniearitas Lingkungan Kerja terhadap Kinerja Guru

\begin{tabular}{|c|c|c|c|c|c|c|}
\hline & & $\begin{array}{l}\text { Sum of } \\
\text { Squares }\end{array}$ & Df & $\begin{array}{l}\text { Mean } \\
\text { Square }\end{array}$ & $\mathbf{F}$ & Sig. \\
\hline \multirow{3}{*}{$\begin{array}{l}\text { Kinerja Guru * } \\
\text { Lingkungan Kerja }\end{array}$} & (Combined) & 935,729 & 25 & 37,429 & 5,981 & 0,004 \\
\hline & Linearity & 702,815 & 1 & 702,815 & 112,299 & 0,000 \\
\hline & $\begin{array}{l}\text { Deviation from } \\
\text { Linearity }\end{array}$ & 232,914 & 24 & 9,705 & 1,551 & 0,252 \\
\hline \multicolumn{2}{|c|}{ Within Groups } & 56,326 & 9 & 6,258 & & \\
\hline \multicolumn{2}{|c|}{ Total } & 992,055 & 34 & & & \\
\hline
\end{tabular}

Pada Tabel di atas terlihat bahwa nilai $F$ hitung pada uji keberartian (linearity) adalah 112.299 dan pada nilai $F$ Hitung pada uji linearitas (Deviation from Linearity) adalah 1,551. Dengan kata lain maka dapat dinyatakan bahwa hubungan antara lingkungan kerja dan kinerja guru bersifat linier. Selanjutnya hasil uji prasyarat ketiga yaitu uji multikoliniearitas yang digunakan untuk mengetahui apakah terdapat hubungan antara variabel independen dalam penelitian. Data yang baik jika tidak terdapat hubungan antara variabel bebas satu dan lainnya. Pengujian multikolinearitas menggunakan bantuan IBM SPSS 22.0 for windows dengan melihat nilai VIF dan Tolerance. Adapun hasil uji multikolinearitas disajikan pada Tabel 7.

Tabel 7. Hasil Uji Multikoliniearitas

\begin{tabular}{|c|c|c|c|c|c|c|c|}
\hline \multirow{2}{*}{ Model } & \multicolumn{2}{|c|}{$\begin{array}{l}\text { Unstandardized } \\
\text { Coefficients }\end{array}$} & \multirow{2}{*}{$\begin{array}{c}\begin{array}{c}\text { Standardized } \\
\text { Coefficients }\end{array} \\
\text { Beta }\end{array}$} & \multirow{2}{*}{$\mathbf{T}$} & \multirow{2}{*}{ Sig. } & \multicolumn{2}{|c|}{$\begin{array}{l}\text { Collinearity } \\
\text { Statistics }\end{array}$} \\
\hline & B & $\begin{array}{l}\text { Std. } \\
\text { Error }\end{array}$ & & & & Tolerance & VIF \\
\hline $\begin{array}{l}\text { (Constant) } \\
\text { Tipe }\end{array}$ & 38,449 & 5,726 & & 6,714 & 0,000 & & \\
\hline $\begin{array}{l}\text { Kepemimpinan } \\
\text { Kepala Sekolah }\end{array}$ & 0,258 & 0,124 & 0,444 & 2,085 & 0,045 & 0,177 & 5,648 \\
\hline Lingkungan Kerja & 0,202 & 0,098 & 0,439 & 2,063 & 0,047 & 0,177 & 5,648 \\
\hline
\end{tabular}


Interpretasi pengujiannya apabila nilai VIF $<10$ dan nilai Tol $>0,1$ maka tidak terjadi gejala multikoliniearitas antar variabel bebas. Hasil pengujian tersebut diperoleh nilai VIF sebesar 5,648<10 dan nilai Tolerance 0,177 >0,1. Ditarik sebuah kesimpulan bahwa tidak terjadi gejala multikolinearitas antar variabel independen. Setelah data memenuhi persyaratan, maka dilakukan analisis lebih lanjut terkait hipotesis penelitian. Penelitian ini dilakukan untuk mengkaji hubungan antara tipe kepemimpinan kepala sekolah dan lingkungan kerja terhadap kinerja guru. Adapun hasil uji hipotesis menggunakan bantuan IBM SPSS 22.0 for windows dengan rumus korelasi product moment disajikan pada Tabel 8.

Tabel 8. Korelasi X1 terhadap Y dan X2 terhadap $Y$

\begin{tabular}{llccc}
\hline & $\mathbf{x 1}$ & $\mathbf{x 2}$ & $\mathbf{Y}$ \\
\hline & Pearson & 1 & $907^{* *}$ & $0,842^{* *}$ \\
x1 & Correlation & & 0,000 & 0,000 \\
& Sig. (2-tailed) & 35 & 35 & 35 \\
N & $0,907^{* *}$ & 1 & $0,842^{* *}$ \\
& Pearson & 0,000 & & 0,000 \\
x2 & Correlation & 35 & 35 & 35 \\
\hline
\end{tabular}

Pada pengujian hipotesis I yaitu koefisien pearson correlation $0,842>0,334$, maka hal ini menandakan bahwa tipe kepemimpinan kepala sekolah terhadap kinerja guru menyatakan bahwa $\mathrm{HO}$ yang tidak terdapat korelasi yang signifikan tipe kepemimpinan kepala sekolah terhadap kinerja guru di SD Gugus Srikandi ditolak dan $\mathrm{Ha}$ yang menyatakan terdapat korelasi yang signifikan tipe kepemimpinan kepala sekolah terhadap kinerja guru di SD Gugus Srikandi diterima.Pada pengujian hipotesis II yaitu koefisien pearson correlation 0,842 >0,334, maka hal ini menandakan bahwa lingkungan kerja terhadap kinerja guru menyatakan bahwa $\mathrm{H} 0$ yang tidak terdapat korelasi yang signifikan tipe kepemimpinan kepala sekolah terhadap kinerja guru di SD Gugus Srikandi ditolak dan $\mathrm{Ha}$ yang menyatakan terdapat korelasi yang signifikan lingkungan kerja terhadap kinerja guru di SD Gugus Srikandi diterima. Selanjutnya untuk mencari hipotesis III digunakan rumus korelasi ganda dibantu dengan menggunakan IBM SPSS Statistic 22.0 disajikan dalam bentuk tabel, sebagai berikut.

Tabel 9. Korelasi X1, X2 terhadap $Y$

\begin{tabular}{ccccc}
\hline Model & $\mathbf{R}$ & R Square & $\begin{array}{c}\text { Adjusted } \mathbf{R} \\
\text { Square }\end{array}$ & $\begin{array}{c}\text { Std. Error of the } \\
\text { Estimate }\end{array}$ \\
\hline 1 & $0,862^{\mathrm{a}}$ & 0,743 & 0,727 & 2,82093 \\
\hline
\end{tabular}

Pada pengujian hipotesis III diperoleh hasil bahwa korelasi ganda dari tipe kepemimpinan kepala sekolah dan lingkungan kerja terhadap kinerja guru sebesar 0,862 $>0,334$, hal ini menandakan bahwa tipe kepemimpinan kepala sekolah dan lingkungan kerja terhadap kinerja guru menyatakan bahwa $\mathrm{HO}$ yang tidak terdapat korelasi yang signifikan antara tipe kepemimpinan kepala sekolah dan lingkungan kerja terhadap kinerja guru di SD Gugus Srikandi ditolak dan Ha yang menyatakan terdapat korelasi yang signifikan antara tipe kepemimpinan kepala sekolah dan lingkungan kerja terhadap kinerja guru di SD Gugus Srikandi diterima. Hasil perhitungan korelasi tipe kepemimpinan terhadap kinerja guru terdapat korelasi yang signifikan antara tipe kepemimpinan kepala sekolah terhadap kinerja guru di SD gugus Srikandi Tahun Ajaran 2020/2021 dapat diterima atau dibuktikan. Dilihat dari nilai korelasi 0,842 yang berada direntang 0,8 - 1 menunjukan korelasi yang sangat tinggi diantara variabel tipe kepemimpinan kepala 
sekolah terhadap kinerja guru. Berdasarkan hasil penelitian ini yang menyatakan terdapat korelasi yang sangat tinggi antara tipe kepemimpinan kepala sekolah terhadap kinerja guru, maka dapat di jelaskan bahwa kepala sekolah sangat berpengaruh bagi kehidupan guru-guru di sekolah untuk mencapai tujuan yang diinginkan. (Elly \& Soraya, 2020) menyatakan bahwa semakin baik kepala sekolah akan mampu mendorong kinerja guru yang semakin meningkat. Peningkatan kinerja guru menunjukkan prestasi guru yang semakin tinggi. Kepala sekolah menjadi penggerak utama dalam mendorong para guru dan pegawai untuk dapat berkinerja tinggi dan membawa perubahan sekolah menuju kualitas yang lebih baik. Selain itu (Hardono, 2017) menyatakan bahwa sukses atau tidaknya suatu sekolah sangat ditentukan oleh kualitas dari kepala sekolahnya terutama dalam memacu semangat kerja guru dan staffnya kedalam suasana yang kondusif yang dapat mempengaruhi guru di sekolahnya dan dapat dijadikan teladan karena dengan semakin baiknya kepemimpinan kepala sekolah tentu akan meningkatkan kinerja guru. Hasil penelitian ini sejalan dengan pendapat (Juniarti, 2020) bahwa peran dari kepala sekolah sebagai seorang pemimpin adalah menjadi kunci dari peningkatan atau perkembangan sekolah guna meningkatkan kinerja dari seorang guru. Peningkatan kinerja dapat tercapai apabila kepala sekolah sebagai pemimpin mampu mengorganisir pembelajaran, siswa maupun guru sebab guru merupakan salah satu faktor penentu tinggi rendahnya mutu hasil pendidikan. Jika guru telah mendapatkan perhatian dan budaya sekolah yang kondusif maka hal itu akan meningkatkan dan mengembangkan kinerja guru khususnya kinerja mengajarnya (Isnaini, 2019; Joo, 2020; Sidabutar et al., 2018).

Hasil perhitungan korelasi lingkungan kerja terhadap kinerja guru menyatakan terdapat korelasi yang signifikan antara lingkungan kerja terhadap kinerja guru di SD Gugus Srikandi Tahun Ajaran 2020/2021 dapat diterima atau dibuktikan dan jika dilihat dari nilai korelasi 0,842 yang berada direntang 0,8-1.0 menunjukan korelasi yang sangat tinggi diantara variabel lingkungan kerja terhadap kinerja guru. Berdasarkan hasil penelitian ini yang menyatakan terdapat korelasi yang sangat tinggi antara lingkungan terhadap kinerja guru. Dapat di jelaskan bahwa lingkungan kerja akan menentukan kenyamanan seseorang dalam bekerja. (Ningsih, 2016) menyatakan bahwa semakin baiknya lingkungan kerja akan mengakibatkan pencapaian kinerja organisasi secara maksimal. Sesuai dengan pendapat (Ansori, 2019) ketika terjadinya perubahan pada lingkungan kerja yang ditandai meningkatnya wawasan dan peningkatan mutu sekolah maka akan berdampak positif terhadap kinerja guru di sekolah tersebut. Berdasarkan hasil penelitian ini dapat dijelaskan saat guru-guru melaksanakan aktivitas dalam kehidupan sehari-hari sangat diperlukannya suatu perhatian terhadap sesuatu yang dilakukan salah satunya di lingkungan tempat kita bekerja. Dengan adanya perubahan dalam lingkungan kerja serta keadaan lingkungan yang kondusif tentunya dapat memberikan rasa yang aman untuk bekerja. Apabila lingkungan kerja yang ada disekitar guru tersebut baik, maka guru-guru pasti mempunyai kinerja yang tinggi sehingga mereka bisa betah di tempat kerjanya untuk melakukan aktivitas apapun itu dan tentunya terjalin kerjasama yang baik dalam sekolah tersebut. Suatu kondisi lingkungan kerja dapat dikatakan baik apabila pegawai dapat melaksanakan kegiatan secara optimal, sehat, aman, dan nyaman sehingga akan memberikan dampak positif terhdap kinerja guru (Sari, 2018; Triastuti, 2019). Sebaliknya jika lingkungan kerja yang tidak memadai akan dapat menurunkan kinerja pegawai. Berdasarkan hal tersebut dapat dikatakan jika lingkungan kerja ditingkatkan maka kinerja pegawai dapat meningkat pula.

Hasil perhitungan korelasi tipe kepemimpinan kepala sekolah dan lingkungan kerja terhadap kinerja guru menyatakan bahwa terdapat korelasi yang signifikan antara tipe kepemimpinan kepala sekolah dan lingkungan kerja terhadap kinerja guru di SD Gugus Srikandi Tahun Ajaran 2020/2021 dapat diterima dan dibuktikan dan nilai korelasi 0,862 yang berada pada kisaran 0,8 - 1,0 berarti tipe kepemimpinan kepala sekolah dan lingkungan kerja memiliki korelasi yang sangat tinggi terhadap kinerja guru. Berdasarkan hasil penelitian ini membuktikan bahwa kepala sekolah yang kepemimpinannya disukai 
guru dan lingkungan kerja yang aman dan nyaman tentunya membuat guru merasa betah untuk bekerja disekolah sehingga akan berdampak positif terhadap kinerja dari seorang guru dan sebaliknya jika kepemimpinan yang tidak disukai maka kinerjanya menjadi tidak baik. Sesuai dengan pendapat (Priyono et al., 2018) bahwa kepala sekolah harus mempunyai jiwa kepemimpinan yang baik dan selalu bersikap tenang dan tegas kepada bawahannya karena hal ini sangat berpengaruh terhadap kinerja guru selain dari kepemimpinan kepala sekolah hal yang dapat mengoptimalkan kinerja guru ditunjang oleh kondisi lingkungan yang sesuai karena Kenyamanan tempat kerja baik secara fisik dan non fisik merupakan harapan bagi setiap guru-guru. (Sumarni, Hasmin \& Mustari, 2017) menyatakan bahwa untuk menunjang kinerja guru dalam proses pembelajaran di sekolah sangat perlu adanya keberadaan dari kepala sekolah untuk memimpin dan memberikan arahan yang baik kepada bawahan karena apapun yang dikerjakan oleh guru pasti meminta pertimbangan dari kepala sekolah dan juga lingkungan kerja yang aman, nyaman tenteram sangat berpengaruh terhadap keberhasilan pendidikan di sekolah tersebut. Selain itu dari hasil penelitian menunjukkan bahwa kepemimpinan, teladan, lingkungan kerja yang nyaman, secara langsung memiliki pengaruh signifikan terhadap kinerja guru sehingga akan mendukung peningkatan mutu pendidikan yang ada disekolah (Prasetyo, 2020; Siagian, 2018). Kinerja guru tidak hanya bersifat individu tetapi juga kelompok sebagai salah satu implementasi kompetensi guru di bidang sosial. Kinerja guru dalam kerja tim juga meningkat berkat tipe kepemimpinan dan iklim kerja. Temuan didukung oleh hasil penelitian lainnya yang menunjukkan bahwa dukungan kepala sekolah memiliki korelasi yang positif dan signifikan terhadap komitmen guru (Huang, 2011).

Pada penelitian ini memberikan implikasi yaitu kepala sekolah yang kepemimpinannya disukai guru dan lingkungan kerja yang aman dan nyaman tentunya membuat guru merasa betah untuk bekerja disekolah sehingga kinerja dari seorang guru menjadi bagus. Untuk menunjang kinerja guru dalam proses pembelajaran di sekolah perlu adanya komunikasi yang baik antara kepala sekolah dalam memberikan arahan yang baik kepada bawahan. Komunikasi yang baik antara guru dan kepalada sekolah akan mendukung terciptanya sekolah yang efektif (Şahenk, 2010). Dengan demikian akan menciptakan lingkungan kerja yang nyaman dan keberhasilkan pendidikan di sekolah akan lebih mudah dicapai. Maka dari itu sangatlah penting untuk dapat meningkatkan kinerja dari seorang guru karena dengan upaya tersebut bisa meningkatkan kualitas pendidikan yang ada di sekolah.

Berdasarkan hasil pengamatan yang dilakukan bahwa tipe kepemimpinan kepala sekolah dan lingkungan kerja yang ada di SD Gugus Srikandi sangat memiliki hubungan yang kuat terhadap kinerja guru yang dapat dilihat dari kemaksimalan kepala sekolah dalam memimpin sekolah tersebut dan lingkungan kerjanya yang optimal dan baik. Sehingga dapat dilihat hasil penelitian ini memiliki korelasi yang sangat tinggi antara tipe kepemimpinan kepala sekolah dan lingkungan kerja terhadap kinerja guru di sekolah tersebut, maka dapat dijelaskan ketika seorang kepala sekolah mempunyai cara memimpin yang baik serta dapat dijadikan teladan oleh guru-guru maka akan berdampak baik terhadap kinerja guru yang disekolah tersebut dan tujuan dari pendidikan di sekolah tersebut bisa terlaksanakan dengan baik dan lancar.

\section{Simpulan}

Berdasarkan penelitian dan pembahasan yang telah dilaksanakan, maka dapat disimpulkan bahwa terdapat korelasi yang signifikan antara tipe kepemimpinan kepala sekolah dan lingkungan kerja terhadap kinerja guru. Sebagai bagian tindak lanjut dari penelitian ini, maka disarankan bagi kepala sekolah untuk dapat mengoptimalkan diri dalam memimpin serta menjalankan tugas dan tanggung jawabnya dengan baik disekolah selain hal tersebut, di dalam kepemimpinannya kepala sekolah harus dapat memahami, mengatasi dan memperbaiki kekurangan-kekurangan yang terjadi di lingkungan kerjanya. 
Sebab guru tentu saja mengharapkan lingkungan tempat mereka bekerja menjadi lingkungan yang aman, nyaman dan tentram. Oleh karena itu semakin baiknya lingkungan kerja dan kepemimpinan kepala sekolah maka kinerja guru menjadi baik serta peneliti lain dapat menjadikan penelitian ini sebagai kajian yang relevan dan referensi untuk melakukan sebuah penelitian.

\section{Daftar Pustaka}

Anam, C. (2018). Pengaruh Motivasi , Kompetensi , Kepemimpinan , Lingkungan Kerja dan Disiplin Kerja Terhadap Kinerja Guru di Sekolah Menengah Kejuruan. Jurnal Manajemen Dan Pendidikan Islam, 4(1), 40-56.

Ansori. (2019). Pengaruh Kompetensi dan Lingkungan Kerja terhadap Kinerja Guru SMA Negeri 1 Kuantan Hilir. Eko Dan Bisnis (Riau Economics and Reviewe), 10(2), 261-271.

Anwar. (2019). Kepemimpinan Kepala Sekolah Dalam Pengembangan Profesionalisme Guru di TK IT Nur Al Izhar Kebonsari. 51-56.

Astuti, W. S. (2018). Hubungan Kepemimpinan Kepala Sekolah Dengan Kinerja Guru Di Smk Swasta Bisnis Manajemen Kecamatan Padang Barat Kota Padang. Jurnal Bahana Manajemen Pendidikan, 7(2), 16-23. https://doi.org/10.24036/bmp.v7i2.5989.

Azis, A. Q., \& Suwatno, S. (2019). Pengaruh Gaya Kepemimpinan Kepala Sekolah Terhadap Kinerja Guru di SMK Negeri 11 Bandung. Jurnal Pendidikan Manajemen Perkantoran, 4(2), 246. https://doi.org/10.17509/jpm.v4i2.18020.

Candra, \& Sakban, A. (2016). Analisis Korelasi Kepemimpinan Kepala Sekolah Dan Kinerja Guru Terhadap Motivasi Belajar Siswa Di SMAN 1 Labuapi Kabupaten Lombok Barat. Jurnal IImiah Mandala Education, 2(2), 53-60.

Eliyanto. (2018). Pengaruh Motivasi Kerja dan Lingkungan Kerja Terhadap Kinerja Guru SMA Muhammadiyah di Kabupaten Kebumen. Jurnal Pendidikan Madrasah, 3(1), 169-181.

Elly, Y., \& Soraya, J. (2020). Kepemimpinan Kepala Sekolah dan Lingkungan Sekolah terhadap Kinerja Guru. Jurnal Penelitian Dan Pendidikan IPS, 14(2), 55-61. https://doi.org/10.21067/jppi.v14i2.4856.

Fachreza, Musnadi, S., \& Majid, M. S. A. (2018). Pengaruh Motivasi kerja, lingkungan kerja, dan budaya organisasi terhadap kinerja karyawan dan dampaknya pada kinerja Bank Aceh Syariah di Kota Banda Aceh. Jurnal Magister Manajemen, 2(1), $115-122$.

Fauzyah. (2020). Hubungan Motivasi Kerja Dengan Kinerja Guru Madrasah. Jurnal Manajemen Pendidikan Islam, 1(1995), 13-25.

Ferawati, A. (2017). Pengaruh Lingkungan Kerja Dan Disiplin Kerja Terhadap Kinerja Karyawan Pt. Cahaya Indo Persada. Jurnal Agora, 5(1), 1-131.

Fredianto, D. (2016). Hubungan antara Motivasi Kerja dan Kedisiplin dengan Kinerja Guru di SD. Jurnal Manajer Pendidikan, 10(4), 354-361.

Hardono. (2017). Kepemimpinan Kepala Sekolah, Supervisi Akademik, dan Motivasi Kerja dalam Meningkatkan Kinerja Guru. Educational Management Journal, 6(1), 26-33.

Harefa, D. (2019). Peningkatan Prestasi Rasa Percaya Diri dan Motivasi Terhadap Kinerja Guru IPA. 13(10), 1773-1786.

Huang, T. M. (2011). The relationship between headmasters' leadership behaviour and teachers commitment in primary schools in the district of Sarikei, Sarawak. Procedia - Social and Behavioral Sciences, 29, 1725-1732. https://doi.org/10.1016/j.sbspro.2011.11.418.

Ideswal. (2019). Kontribusi Iklim Sekolah Dan Kepemimpinan Kepala Sekolah Terhadap Kinerja Guru Sekolah Dasar. Jurnal Basicedu, 3(2), 524-532.

Isnaini. (2019). Kepemimpinan Kepala Sekolah Sebagai Seorang Supervisor Dalam Pengawasan Kinerja Guru Di Sekolah Dasar. El-Tsaqafah: Jurnal Jurusan PBA, 53(9), 1689-1699. 
Joo, Y. H. (2020). The effects of distributed leadership on teacher professionalism: The case of Korean middle schools. International Journal of Educational Research, 99(August 2019). https://doi.org/10.1016/j.ijer.2019.101500.

Juniarti. (2020). Pengaruh Kepemimpinan Kepala Sekolah dan Disiplin Guru terhadap Kinerja Guru. Journal of Education Research, 1(2), 173-188. https://doi.org/10.47467/reslaj.v1i2.108.

Mbuik, H. B. (2019). Pengaruh Kepemimpinan Kepala Sekolah terhadap Penerapan Manajemen Berbasis Sekolah di SD. Indonesian Journal of Primary Education, 3(2), 28-37.

Muslimin. (2019). Pengaruh Gaya Kepemimpinan Dan Kemampuan Manajerial Kepala Sekolah Dasar Terhadap Kinerja Guru. 13. https://doi.org/10.31227/osf.io/da4ym.

Nainggolan, M. C., Lie, D., Butarbutar, M., \& Nainggolan, L. E. (2018). Pengaruh Gaya Kepemimpinan Kepala Sekolah Dan Lingkungan Kerja Terhadap Kinerja Guru Yayasan Perguruan Maria Goretti Pematangsiantar. Maker:Jurnal Manajemen, 4(1), 10.

Nefrida. (2016). The Effect of Teacher Competence and Work Environment on Performance of Vocational High School I Teachers in Jambi. Pendidikan Dan Keguruan, 1(1), 1-15.

Ningsih, P. (2016). Pengaruh Komitmen, Kompetensi, Dan Lingkungan Kerja Terhadap Kinerja Guru Di Kecamatan Pasangkayu Kabupaten Mamuju Utara (Study Kasus pada SMA Negeri 1 Pasangkayu dan MA DDI Pasangkayu). Kataogis, 5(7), 181190.

Prasetyo, E. B. (2020). Pengaruh motivasi, kepemimpinan dan lingkungan kerja terhadap kinerja guru melalui kompetensi guru SMK Negeri Sekar Kabupaten bojonegoro. Jurnal Mitra Pendidikan, 2(1), 11-22.

Priyono, B. H., Qomariah, N., \& Winahyu, P. (2018). Pengaruh Gaya Kepemimpinan, Motivasi Guru Dan Lingkungan Kerja Fisik Terhadap Kinerja Guru Sman 1 Tanggul Jember. Jurnal Manajemen Dan Bisnis Indonesia, 4(2), 144. https://doi.org/10.32528/jmbi.v4i2.1758

Putri. (2017). Pengembangan profesi guru dalam meningkatkan kinerja guru (Professional development of teachers in improving the performance of teacher). Jurnal Pendidikan Manajemen Perkantoran, 2(2), 10.

Rosaliawati, B. N., Mustiningsih, M., \& Arifin, I. (2020). Hubungan Gaya Kepemimpinan Kepala Sekolah Dan Kinerja Guru. Jurnal Administrasi Dan Manajemen Pendidikan, 3(1), 61-71. https://doi.org/10.17977/um027v3i12020p61.

Şahenk, S. S. (2010). Characteristics of the headmasters, teachers and students in an effective school. Procedia - Social and Behavioral Sciences, 2(2), 4298-4304. https://doi.org/10.1016/j.sbspro.2010.03.682.

Sampurno. (2015). Kepemimpinan Kepala Sekolah, Lingkungan Kerja, Motivasi Kerja, dan Kinerja Guru di Smk Negeri 4 Pandeglang. Jurnal Pendidikan Ekonomi Dan Bisnis, 3(2), 165-180.

Sari, P. I. (2018). Pengaruh Lingkungan Kerja dan Motivasi Kerja Terhadap Kinerja Guru SMK Assalam Depok. Jurnal Pendidikan Ekonomi Dan Kewirausahaan, 1(1), 110. https://doi.org/10.30868/ad.v4i01.735.

Siagian. (2018). Pengaruh Gaya Kepemimpinan Dan Lingkungan Kerja Terhadap Kinerja Karyawan Dengan Kepuasan Kerja Sebagai Variabel Intervening. Maneggio: Jurnal Ilmiah Magister Manajemen, 1(1), 59-70. https://doi.org/10.30596/maneggio.v1i1.2241.

Sidabutar, R. U. O., Lie, D., Efendi, E., \& Inrawan, A. (2018). Pengaruh Kepemimpinan Kepala Sekolah Dan Budaya Sekolah Terhadap Kinerja Guru Pada Smp Negeri 1 Panei. SULTANIST: Jurnal Manajemen Dan Keuangan, 5(2), 38-46. https://doi.org/10.37403/sultanist.v5i2.93.

Sumarni, Tamsah, H., \& Mustari. (2017). Pengaruh Supervisi Akademik Pengawas Sekolah, Kepemimpinan Kepala Sekolah dan Lingkungan Kerja terhadap Kinerja Guru SMK Negeri Se-Kecamatan Tamalate Kota Makassar. Jurnal Mirai 
Management, 2(1), 149-163.

Suryani, L., Sahono, B., \& Somantri, M. (2017). Korelasi Kepemimpinan Kepala Sekolah dan Disiplin Antara Guru Terhadap Kinerja Guru Di SMPN Simpang Kosgoro Kab. Musi Rawas. Jurnal Manajer Pendidikan, 11(3).

Triastuti, D. A. (2019). Pengaruh Lingkungan Kerja, Kompetensi Dan Iklim Organisasi Terhadap Kinerja Pegawai. Journal of Management Review, 2(2), 203. https://doi.org/10.25157/jmr.v2i2.1796. 